\title{
Study of the Soil Moisture Content and the Tractor Speed on the Performance Efficiency of the Machinery Unit
}

\author{
Hussain A. Jebur ${ }^{1}$, Yasir A. A. Alsayyah ${ }^{1}$ \\ ${ }^{I}$ (Dept. of Agric. Mach. and Equip, Coll. of Agric. / Univ. of Baghdad, Iraq)
}

\begin{abstract}
A field experiment was conducted in the experiment fields of the college of agriculture - Abu ghraib - Baghdad University, 2016 in a silt clay loam soil, to study the effect of soil moisture content and the speed of the tractor on some tractor performance indicators and some of soil physical characteristics, ArmaTrac 845e and ITM 285 New tractor with sweep plough as a machinery unit were used in this study. Two soil moisture content under $18-20 \%$ and $14-16 \%$ which represented main plot, Three types of plough included: moldboard, chisel and sweep which represented subplot, five levels of foreword speeds of tractor included: $1.5,2.53,3.75,5.3$ and $6.71 \mathrm{~km} / \mathrm{hr}$ which represented sub-subplot. Slippage percentage, Pull force, Effective field capacity, soil moisture level and soil bulk density were measure in this experiment. Split-split plot with complete randomized block design with three replication were used in this study, and Least significant differences (LSD) was used to compare the means of treatments at 0.05 levels. The obtained results, for the range of tests, showed that the Reducing soil moisture content from $18-20 \%$ to $14-16 \%$ caused decreasing slippage percentage by $31.34 \%$ and force pull by $26.14 \%$ and the low value of soil bulk density from 1.25 $\mathrm{g} / \mathrm{cm} 3$ to $1.24 \mathrm{~g} / \mathrm{cm} 3$ and low soil moisture level by $20.92 \%$ to $18.76 \%$ and increased effected field capacity by $12.5 \%$. Increased tractor speed operation led to increase the percentage of slippage and force pull and production field and soil bulk density and the weighted reduce soil moisture level. The interaction between soil moisture content $14-16 \%$ and the speed $1.5 \mathrm{~km} / \mathrm{hr}$ got a less percentage of slippage $6.36 \%$ and less force pull $6.26 \mathrm{kN}$ and less soil bulk density $1.12 \mathrm{~g} / \mathrm{cm} 3$, And the interaction between soil moisture content $14-16 \%$ and speed $6.71 \mathrm{~km} / \mathrm{hr}$ got higher value of the effective field capacity $1.57 \mathrm{he} / \mathrm{hr}$. And the interaction between soil moisture content $18-20 \%$ and the speed $1.5 \mathrm{~km} / \mathrm{hr}$ gave a higher soil moisture level $21.25 \%$.
\end{abstract}

Keywords: Sweep, plough, moisture, speed, tractor.

\begin{tabular}{|l|l|}
\hline Nomenclature & \\
\hline $\mathrm{S}$ & effective tractor speed $(\mathrm{km} / \mathrm{hr})$ \\
\hline $\mathrm{TS}_{1}$ & Forward speed without load km/h. \\
\hline $\mathrm{TS}_{2}$ & Forward speed with load $\mathrm{km} / \mathrm{h}$. \\
\hline $\mathrm{S}$ & Slip \% \\
\hline FT & Net Drawbar Pull $(\mathrm{kN})$ \\
\hline FPU & Tractive Force $(\mathrm{kN})$ \\
\hline FRM & Rolling Resistance $(\mathrm{kN})$ \\
\hline E.F.C & effective field capacity $(\mathrm{he} / \mathrm{hr})$ \\
\hline W & effective plough width $(\mathrm{m})$ \\
\hline$\varphi t$ & efficiency field $(\%)$ \\
\hline$\rho b$ & Soil bulk density $\left(\mathrm{gm} / \mathrm{cm}^{3}\right)$ \\
\hline Ms & dry weigh $(\mathrm{gm})$ \\
\hline Vt & total volume $\left(\mathrm{cm}^{3}\right)$ \\
\hline $\mathrm{MC}$ & soil moisture level $(\%)$ \\
\hline Ww & wet weigh $(\mathrm{gm})$ \\
\hline Wd & dry weigh $(\mathrm{gm})$ \\
\hline
\end{tabular}

\section{Introduction}

The mechanization field of the agricultural work cares foremost, the development of human And his community comprehensive and integral development as provided by the means and methods of intellectual, artistic, social and economic for the development and prosperity to his society, also cares operations training and preparation of Human cadres technically and administrative to operate and management of agricultural equipment with high efficiency. This in turn encourages states to expand the use of units of agricultural mechanization to provide human capital and raising the quality of agricultural products, But the development did not seem obvious unless in the current century. So it was said that $85 \%$ of modern agriculture problems that require engineering solutions, these problems need to be concerted efforts of team of engineers, plant scientists or insect's scientists and lands scientists depending on type of subject. A wide range of agricultural operations are carried out using tractors to provide pull and propulsion. Over the past few decades tractor sizes have 
increased steadily. As tractors increase in power, the main limitations to performance are limitations of the traction device imposed by the terrain over which they operate [19]. Through findings [2] when studying the performance of different ploughs inject pesticide Al-tervlan under the surface of the soil to plough infrastructure was sliding ratio less than a chisel plough and each velocities used in the experiment where he scored the proportion of sliding $8.75 \%$ with record plough Digger proportion sliding of $11.49 \%$, and plough the underlying record productivity of field rate was higher than the moldboard plough inverter and for all velocities values, and was 0.46 he $/ \mathrm{h}$ with the moldboard plough record productivity of a field $0.32 \mathrm{he} / \mathrm{h}$, as it was the proportion of combat and discourage the bushes using a plough infrastructure higher than the chisel and moldboard plough. [18] that when you work less quickly as possible from the process without affecting the time required for the completion of agricultural operations, is reduced slipping and this is the provision of lost capacity due to slip and use the time properly and then increase productivity. The findings of her patience appears, (2011) that an increase in the operation speed of ploughing affected significantly in the percentage of sliding so that slipping increased $9.42 \%$ to $11.58 \%$, up speed $3.21 \mathrm{~km} / \mathrm{h}$ to $5.37 \mathrm{~km} / \mathrm{h}$ and then to $13.81 \%$ at a speed $7.04 \mathrm{~km} / \mathrm{h}$, and the reason is not to grab the wheel tractors to the surface of the soil's capacity sufficiently to overcome the slide. Reach [3] through the findings that the drawbar pull is proportional to the speed and recorded the lowest drawbar pull has $9.66 \mathrm{kN}$ when speed $2.9 \mathrm{~km} / \mathrm{h}$, while the recorded has a higher drawbar pull $10.9 \mathrm{kN}$ when Speed $5.62 \mathrm{~km} / \mathrm{h}$. [16] showed that the actual field production of machinery unit affected by the moisture content of the soil and the speed of the tractor operation, and has been getting the best productivity when humidity (16-18\%), and increase speed operation led to increased productivity. Bulk density is the ratio between the soil dry weight to the total soil sample size, and there are several factors that affect the bulk density and including: - the transaction type and the machine used and the type of tissues soil and the amount of compaction of soil and punish wettability and drought and the amount of organic matter. [7]. The tillage process increases the surface of the soil exposed to the sun space and be a dirt blocks exposed to the wind, and this leads to increased evaporation of soil moisture, and this is the moisture content of soils ploughed less than the soil is ploughed, and when compared to conventional tillage system of zero tillage system, the rate of evaporation is reduced when no tillage and also increase soil water storage system. [9]. High tractor power than the implement - needed causes a soil compaction and lower operation efficiency due to the increase of the tractor weight and the fuel consumption and also high fixed cost compared with the matched tractor, low tractor power than the implement needed causes a power loss and tire wearing because of the slippage. This study was carried out to help for selecting the suitable tractor with the implement or vise versa. The purpose of this study was to evaluate the effect of forward speed and soil moisture content on tractor performance parameters, namely work-rate, slip and drawbar pull.

\section{Materials And Methods}

The experimental work was carried out in one of college of agricultural - university of Baghdad - Abu ghraib for 2016 in a silty clay loam soil, at plough depth $20 \mathrm{~cm}$ and speed tractor $3.95 \mathrm{~km} / \mathrm{hr}$, the soil properties was:

\begin{tabular}{|c|c|c|c|}
\hline \multicolumn{2}{|l|}{ Character } & Value & unit \\
\hline \multicolumn{2}{|l|}{ Bulk density } & 2.65 & $\mathrm{gm} / \mathrm{cm}^{3}$ \\
\hline \multicolumn{2}{|c|}{ Density of the soil } & 1.43 & $\mathrm{gm} / \mathrm{cm}^{3}$ \\
\hline \multicolumn{2}{|l|}{ Porosity } & 46 & $\%$ \\
\hline \multicolumn{2}{|c|}{ Electrical conductivity } & 3.7 & $\mathrm{ds} / \mathrm{m}$ \\
\hline \multicolumn{2}{|c|}{ Water conductivity } & 0.6 & $\mathrm{~cm} / \mathrm{m}$ \\
\hline \multirow[t]{3}{*}{ Soil texture } & Sand & 11 & $\%$ \\
\hline & Clay & 31 & $\%$ \\
\hline & Silt & 58 & $\%$ \\
\hline \multicolumn{2}{|l|}{ Soil type } & silty clay loam & \\
\hline \multicolumn{2}{|c|}{ Soil penetration resistance } & 5.18 & $\mathrm{kpa}$ \\
\hline
\end{tabular}

\section{Machine Used:}

The first tractor used was Armatrac854e2010 it features (4wd ) (83 hp) (3000 r.p.m), And the second was ITMNEW2852013 it features ( $2 \mathrm{wd}$ ) (80 hp) (2500 r.p.m ), Moldboard plough ( width $105 \mathrm{~cm}$ ) ( 3 board ), chisel plough $(200 \mathrm{~cm})(11$ board $)$, sweep plough $(200 \mathrm{~cm})(2$ board $)$.

\section{Parameter measurement:}

\section{1- Wheel slip (S):}

The slippage percentage was measured by using the following formula: - [20] and [14]:

$$
S=1-\frac{T S_{2}}{T S_{1}} \times 100
$$


2- Drawbar Pull:- [6] :

FT $=$ FPU - FRM $\quad \ldots . .(2)$

3- Effective field capacity:- [13] :

$$
\text { E. F. } C=\frac{W \times S}{10} \times \varphi t
$$

4- Soil bulk density:- [8]:

$$
\rho b=\frac{M s}{V t}
$$

5- Soil moisture level : [10] :

$$
\mathrm{MC}=\frac{W_{\mathrm{w}}-\mathrm{Wd}}{\mathrm{Wd}} \times 100
$$

\section{1- Slippage (\%)}

\section{Results And Discussion}

Results illustrated in Fig (1) shows the effect of forward speed, moisture content and primary tillage equipment and their overlaps on the wheel slip is illustrate in Fig (1). As seen from the Figure, moisture content was significant effect on slippage, where the content (14-16\%) scored less average and it was $11.26 \%$, while the content (18-20\%) scored largest value it was $14.79 \%$ and this is consistent with the results of [17]. Tractor speed was significant effect on slippage, where the speed $1.5 \mathrm{~km} / \mathrm{hr}$ scored less average and it was $8.13 \%$, while the speed $6.71 \mathrm{~km} / \mathrm{hr}$ scored largest value and it was $18.16 \%$, this is consistent with the results of [11] and [12]. The type of tillage equipment was significant effect on wheel slip, the moldboard plow scored the highest average was $14.13 \%$ followed by chisel plow $13.22 \%$ then sweep plow who scored lowest value was $11.19 \%$. So the Fig (1) indicate that the interaction between primary tillage equipment, forward speed and moisture content was significant on the wheel slip, whereas the triple overlap between the forward speed $6.71 \mathrm{~km} / \mathrm{h}$, Moldboard plough and moisture content $(18-20 \%)$ led to obtain the highest wheel slip was $20.52 \%$.

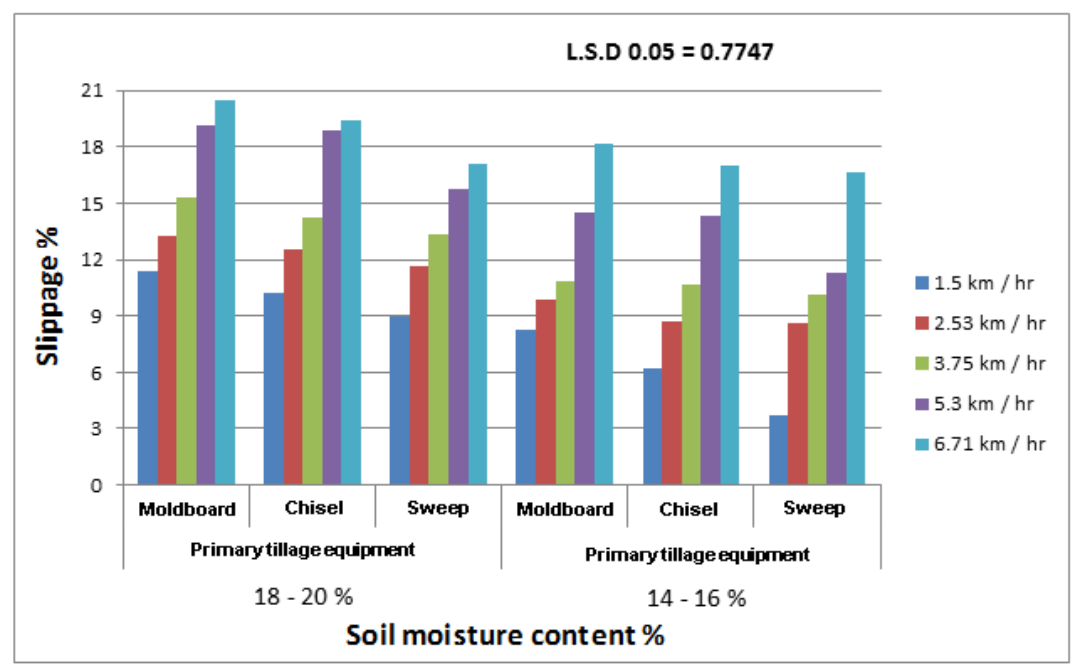

Fig (1) effect soil moisture content, tractor speed and equipment on slippage

\section{2- Drawbar pull (kN)}

Fig (2) shows the effect of the forward speed, moisture content and primary tillage equipment and their overlaps on the drawbar pull is illustrate in Fig (2). As seen from the Figure, moisture content was significant effect on drawbar pull, where the content $(14-16 \%)$ scored less average and it was $8.99 \mathrm{kN}$, while the content $(18-20 \%)$ scored largest value it was $11.34 \mathrm{kN}$. Tractor speed was significant effect on drawbar pull, where the speed $1.5 \mathrm{~km} / \mathrm{hr}$ scored less average and it was $7.43 \mathrm{kN}$, while the speed $6.71 \mathrm{~km} / \mathrm{h}$ scored highest value it was $13.29 \mathrm{kN}$, and this is consistent with the results of [5]. The type of tillage equipment was significant effect on drawbar pull, the sweep plow scored the less average was $9.07 \mathrm{kN}$ followed by chisel plow $10.23 \mathrm{kN}$ then moldboard plow who scored largest value was $11.19 \mathrm{kN}$. So the Fig (2) indicate that the interaction between primary tillage equipment, forward speed and moisture content was significant on the drawbar pull, whereas the triple overlap between the forward speed $6.71 \mathrm{~km} / \mathrm{h}$, Moldboard plough and moisture content $(18-20 \%)$ led to obtain the highest drawbar pull was $15.13 \mathrm{kN}$. 


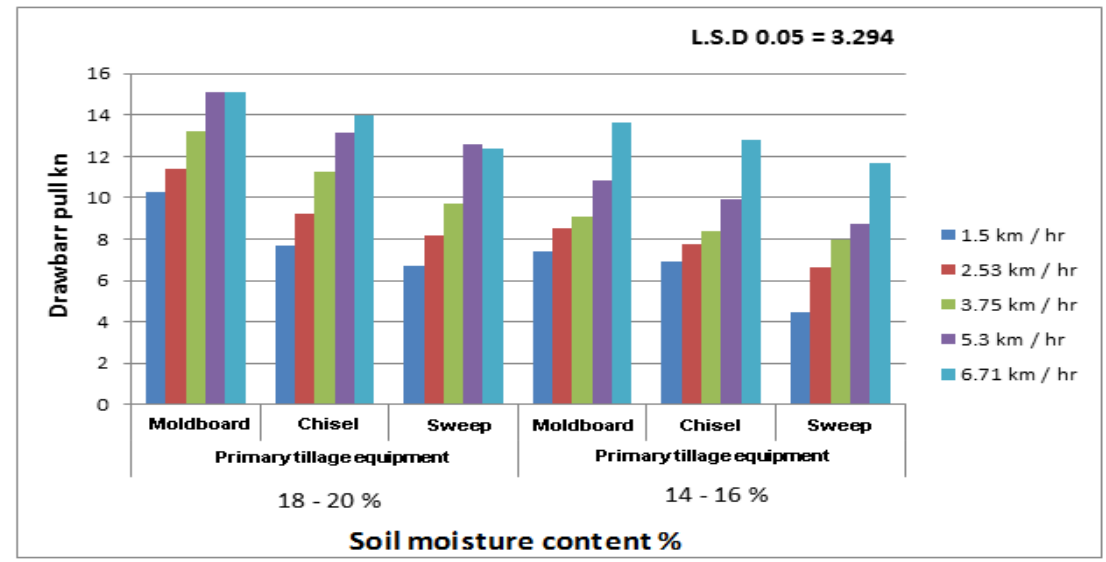

Fig (2) effect soil moisture content, tractor speed and equipment on drawbar pull

\section{3 - Effective field capacity (he/hr)}

Results illustrated in Fig (3) shows the effect of forward speed, moisture content and primary tillage equipment and their overlaps on the effective field capacity is illustrate in Fig (3). As seen from the figure, moisture content was significant effect on effective field capacity, where the content (14 - 16\%) scored largest average and it was $(0.9 \mathrm{he} / \mathrm{hr})$, while the content $(18-20 \%)$ scored less value it was $(0.8 \mathrm{he} / \mathrm{hr})$. Tractor speed was significant effect on effective field capacity, where the speed $1.5 \mathrm{~km} / \mathrm{hr}$ scored less average and it was $(0.3$ he/hr), while the speed $(6.71 \mathrm{~km} / \mathrm{hr}$ ) scored largest value and it was $1.51 \mathrm{he} / \mathrm{hr}$, and this is consistent with the results of [4] and [5]. The type of tillage equipment was significant effect on effective field capacity, the chisel plow scored the high average was $0.99 \mathrm{he} / \mathrm{hr}$ followed by sweep plow $0.87 \mathrm{he} / \mathrm{hr}$ then moldboard plow who scored lowest value was $0.69 \mathrm{he} / \mathrm{hr}$. So the Fig (3) indicate that the interaction between primary tillage equipment, forward speed and moisture content was significant on the effective field capacity, whereas the triple overlap between the forward speed $6.71 \mathrm{~km} / \mathrm{h}$, chisel plough and moisture content $(14-16 \%)$ led to obtain the highest effective field capacity was $1.97 \mathrm{he} / \mathrm{hr}$.

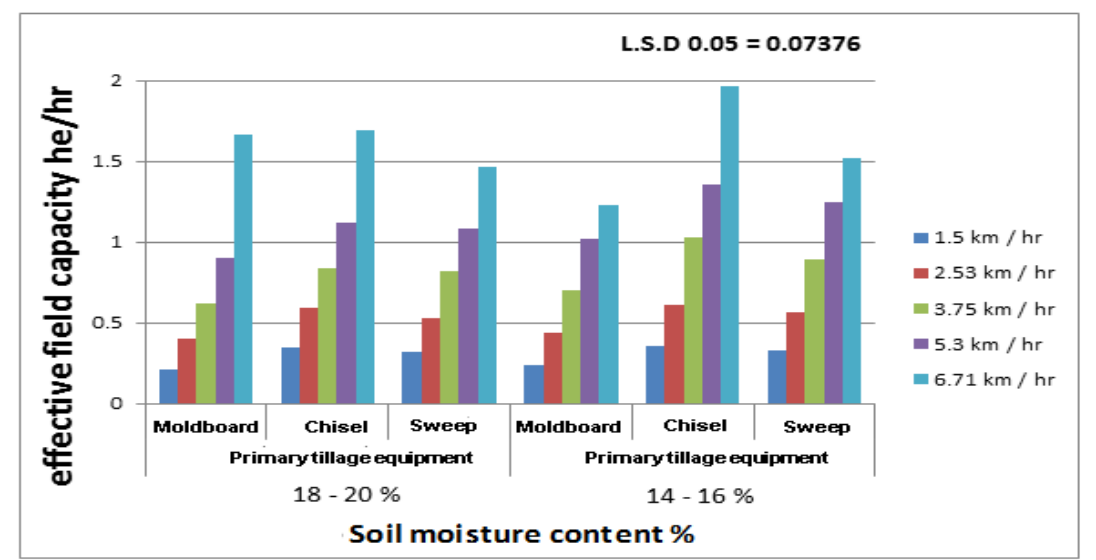

Fig (3) effect soil moisture content, tractor speed and equipment on effective field capacity

\section{4- Soil bulk density $\left(\mathrm{gm} / \mathrm{cm}^{3}\right)$}

Fig (4) shows the effect of the forward speed, moisture content and primary tillage equipment and their overlaps on the soil bulk density is illustrate in Fig (4). As seen from the figure, moisture content was significant effect on soil bulk density, where the content $(14-16 \%)$ scored less average and it was $\left(1.24 \mathrm{gm} / \mathrm{cm}^{3}\right)$, while the content $(18-20 \%)$ scored largest value and it was $1.25 \mathrm{gm} / \mathrm{cm}^{3}$, and this is consistent with the results of [1]. Tractor speed was Significant effect on soil bulk density, where the speed $(1.5 \mathrm{~km} / \mathrm{hr})$ scored less average and it was $1.13 \mathrm{gm} / \mathrm{cm}^{3}$, while the speed $(6.71 \mathrm{~km} / \mathrm{hr})$ scored largest value and it was $\left(1.37 \mathrm{gm} / \mathrm{cm}^{3}\right)$, and this is consistent with the results of [3]. The type of tillage equipment was significant effect on soil bulk density, the moldboard plow scored the high average was $1.27 \mathrm{gm} / \mathrm{cm}^{3}$ followed by chisel plow $1.25 \mathrm{gm} / \mathrm{cm}^{3}$ then sweep plow who scored lowest value was $1.23 \mathrm{gm} / \mathrm{cm}^{3}$. So the Fig (4) indicate that the interaction between primary tillage equipment, forward speed and moisture content was significant on the soil bulk density, whereas the triple overlap between the forward speed $6.71 \mathrm{~km} / \mathrm{h}$, Moldboard plough and moisture content $(18-20 \%)$ led to obtain the highest soil bulk density was $1.4 \mathrm{gm} / \mathrm{cm}^{3}$. 


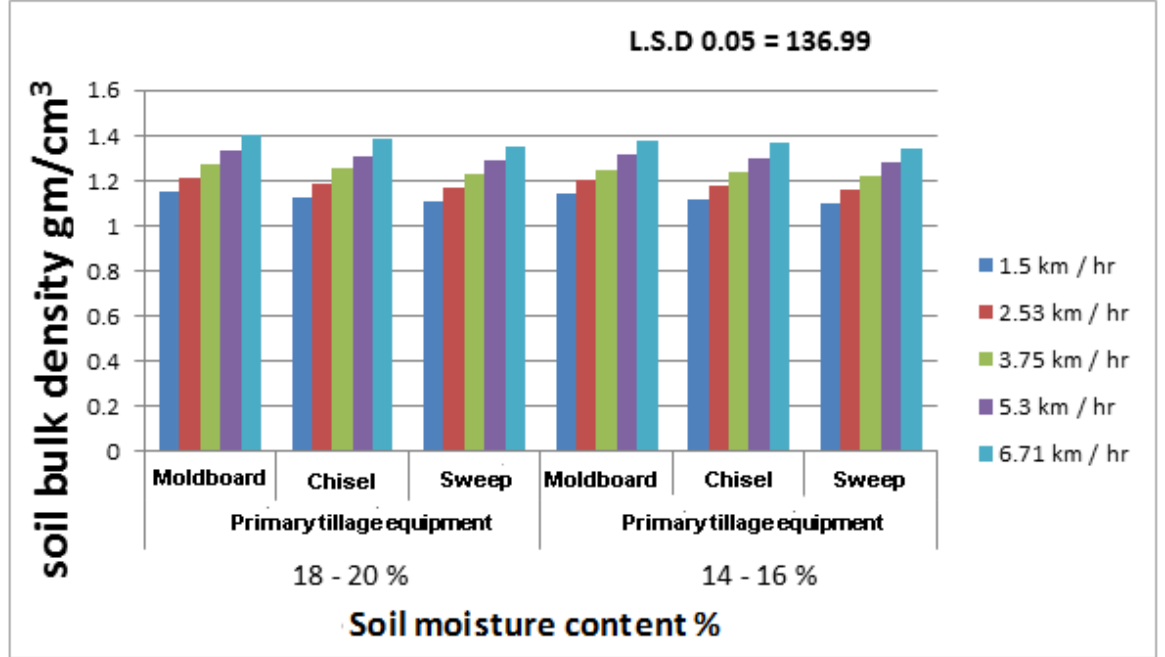

Fig (4) effect soil moisture content, tractor speed and equipment on soil bulk density

\section{5- Soil moisture level (\%)}

Fig (5) shows the effect of the forward speed, moisture content and primary tillage equipment and their overlaps on the soil moisture level is illustrate in Fig (5). As seen from the figure, moisture content was significant effect on soil moisture level, where the content (14 - 16\%) scored less average and it was $18.76 \%$, while the content $(18-20 \%)$ scored largest value and it was $20.92 \%$. Tractor speed was significant effect on soil moisture content, where the speed $1.5 \mathrm{~km} / \mathrm{hr}$ scored largest average and it was $20.19 \%$, while the speed $6.71 \mathrm{~km} / \mathrm{hr}$ scored less value and it was $19.46 \%$. The type of tillage equipment was significant effect on soil moisture level; the sweep plow scored the high average was $20.68 \%$ followed by chisel plow $19.83 \%$ then moldboard plow that scored lowest value was $19.02 \%$. So the Fig (5) indicate that the interaction between primary tillage equipment, forward speed and moisture content was significant on the soil moisture level, whereas the triple overlap between the forward speed $1.5 \mathrm{~km} / \mathrm{h}$, sweep plough and moisture content $(18-20 \%)$ led to obtain the highest soil moisture level was $22.18 \%$.

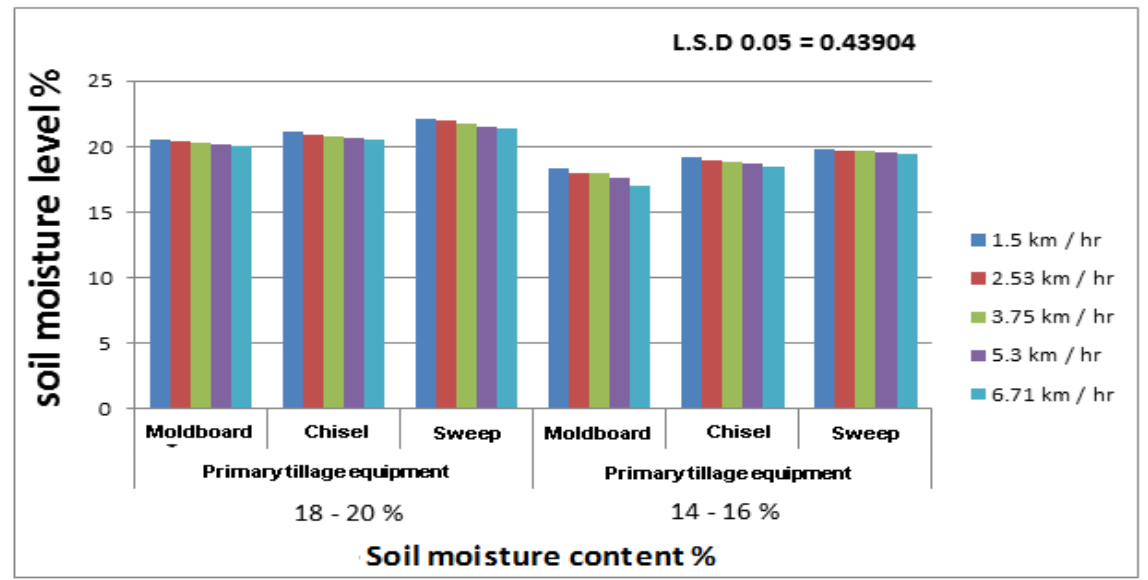

Fig (5) effect soil moisture content, tractor speed and equipment on soil moisture level

\section{Conclusion}

The main results in this study can be summarized as following:

1- Reducing soil moisture content from $18-20 \%$ to $14-16 \%$ caused decreasing slippage percentage and force pull and the low value of soil bulk density and low soil moisture level and increased effected field capacity.

2- Increased tractor speed operation led to increase the percentage of slippage and force pull and Production Field and soil bulk density and the soil moisture level.

3- The interaction between soil moisture content $14-16 \%$ and the speed $1.5 \mathrm{~km} / \mathrm{hr}$ got a less percentage of slippage and less force pull and less soil bulk density, And the interaction between soil moisture content 14 - 16 $\%$ and speed $6.71 \mathrm{~km} / \mathrm{hr}$ got higher value of the effective field capacity, And the interaction between soil moisture level $18-20 \%$ and the speed $1.5 \mathrm{~km} / \mathrm{hr}$ gave a higher soil moisture level. 


\section{Acknowledgements}

First of all I'd like to gratitude my wife and each on who provided assistance for me to complete this work.

\section{References}

[1] Abdali , Omar ania Abdullah, the performance of the tractor Massey Verxsen (MF - 4260) with the moldboard plough quadruple the inverter and the effect of overlap in some physical properties of the soil, Master Thesis doctoral diss., Department of machinery and agricultural machinery, College of the implant , the University of Baghdad, 2000.

[2] Al- Qaraghuly, Omar . G. H, Comparison performance deferent Ploughs to injection trifluralin herbicide below the soil, Master Thesis doctoral diss., Department of machinery and agricultural machinery , College of the implant, the University of Baghdad, 2011.

[3] Alaridhee , Jawad kadhim zeyad, Effect of Tractor's Type, Speed and Tillage Depth in Some technical indicators of machine unit's and Physical characteristics of the Soil, Master Thesis doctoral diss., Department of machinery and agricultural machinery , College of the implant, the University of Baghdad, 2011.

[4] Alroshadi, zina Allawi Habib and Abdul Razzak Abdul Latif Jassim, A study of some technical and economic indicators of the machinary unit using different Quicken, Iraqi Journal of Agricultural Sciences: 46(6), 2015, 1060-1068.

[5] Ashour, Dheyaa S. and Hussain A. Safi, The effect of chisel plough type, Operating depth and forward speed on the energy requirement and Some filed performance indicators in silty clay soil, Basrah Journal for research , No. (41), 2015 (Part B.3).

[6] Barger , E. L. , J. B. Liljedahl, W. M. Carleton and E. G. Mc. Kibben, Tractors and their Power Units (John Wiley and Sons , Inc. , Second edition, New York, USA, 1963).

[7] Baver, L. D. , W. H. Gardner and W. R. Gardner, Soil Physics, Fourth Edition (John Wiley and Sons , Inc. , Second edition , New York, USA, 1972)

[8] Black , C. A. , D. D. Evans , J. L. White , L. E. Ensminger and F. E. Clark, Method of Soil Analysis ( part 1 ), Physical and Mineralogical Properties, Including Statistics of Measurements and Sampling (American Society of Agronomy , Inc. , Publisher Madison, Wisconsin, U.S.A, 1965) $357-557$.

[9] Blevins, R.L. ; D. Cook , S.H. Phillips and R.E. Philips, Influence of no-tillage on soil moisture, Agro. J: 63, 1971,593 - 596.

[10] Gardner, W. H., Water content in Black, Method of soil analysis, part ( 1 ) (1965) 82 - 127.

[11] Jebur, Hussein Abbas, Evaluation Performance Of Transport Vehicle On Different Surfaces, International Journal Of Engineering Sciences And Research Technology ( IJESRT ): 4(10), 2015, 228 - 233.

[12] Jebur, Hussein Abbas, The Use Of Variable Weight On Rear Wheels In The Evaluation Performance Of Ploughing Operation, Elixir Agriculture: (95), 2016, 40782 - 40786

[13] Kepner, R. A. , R. Bainer and E. L. Barger, Principles of farm Machinery, third edition (AVI Publishing Company , Inc. , Westport , Connecticut, U.S.A, 1982).

[14] Sharma, D. N. , and S. Mukesh, Design of Agricultural Tractor, principles and problems, First Edition (Published by Shri Sunil Kumar Jain for Jain Brothers, New Delhi-110005, ISBN: 978-81-8360-123-8, 2010).

[15] Suber, Alaa Kamel, Effect of ploughing depths , speed and removing the weights from the New Holland tractor in some performance indicators of machine unit and soil bulk density, Master Thesis., Department of machinery and agricultural machinery , College of the implant, the University of Baghdad, 2011.

[16] Talabani, Jinan Hukmate Namik and Abdul Sattar Mohammed Ali Jassim, the effect of soil moisture and accelerated the jars and the overlap between them in the production and some of the qualities of the physical soil using a disc plough triple, Journal of the Iraqi Agricultural Sciences: Vol. 37 Issue (1) : 2006, 15 - 20.

[17] Talabani, Jinan hukmate Namik, the effect of interactions of soil moisture and deep tillage and accelerated the jars in productivity and some of the qualities of the physical soil using disc plough triangular, Master Thesis., Department of machinery and agricultural machinery, College of the implant, the University of Baghdad, 2002.

[18] Woerman , G. R. and L. Bashford, How much does front wheel assist really help ?, Iraqi Journal of Agricultural Sciences: Agric. Eng. , ( 65 ) : 1984, 31 - 36.

[19] Wulfsohn D, et al. Tractive characteristics of radial ply and bias ply tyres in California soil. Journal of Terramechanics;25(2) 1988 $111 \pm 34$

[20] Zoz, Frank M. Predicating tractor field performance, Transactions of Action ASAE, 15: 1972, 249 - 255. 